\title{
1 Korinthe 3:21-23
}

\author{
M. Bot
}

21 Laat daarom niemand roemen in mensen, want alles is van jullie: 22 hetzij Paulus, hetzij Apollos, hetzij Kefas, hetzij de wereld, hetzij het leven, hetzij de dood, hetzij tegenwoordige dingen, hetzij toekomstige dingen, alles is van jullie. 23 Jullie echter zijn van Christus en Christus is van God.

Het leven in de christelijke gemeente kent naast zijn verrassingen ook zo zijn sleur. Bepaalde patronen herhalen zich, de discussies zijn soms zo voorspelbaar. Wie in de christelijke gemeente leidinggeeft komt bijvoorbeeld op verschillende manieren partijschappen tegen. Onder gemeenteleden of onder kerkenraadsleden, voor of tegen een predikant. En er worden loopgraven betrokken in de strijd om kleinigheden die soms nauwelijks een band hebben met de inhoud van het evangelie. Hoe ga je daarmee om? Met algemene vermaningen als 'Laten we elkaar liefhebben', 'Laten we elkaar vasthouden' of 'Jezus wil dat we één zijn' voel je je al snel verlegen, want dergelijke aansporingen gaan over de hoofden heen. Hoe geef je goed geestelijk leiding in de christelijke gemeente rond de zaken van alledag?

Paulus' eerste brief aan Korinthe is in dit kader een goede leerschool. Ook Paulus wordt geconfronteerd met partijschappen en zaken die zo weinig inhoudelijk met het evangelie lijken samen te hangen. Hoe gaat hij daarmee om? Vanuit zijn brief aan de Romeinen weten we dat hij op hoog niveau theologisch kan reflecteren. Maar hoe vertaalt hij dat dan door naar de praktijk van het gemeenteleven? In 1 Korinthe wordt goed zichtbaar hoe hij bij praktische adviezen uitkomt die theologisch en retorisch sterk in elkaar zitten. 1 Korinthe laat zien dat het in het geestelijk leidinggeven aan de gemeente niet alleen gaat om het hebben van goede theologische inzichten, maar ook om geestelijke wijsheid om deze inzichten concreet toe te passen en goed te communiceren.

Partijschappen in de gemeente rond het leiderschap lijken misschien niet al te theologische kwesties. Misschien moet er gewoon een mediator aan te pas komen, en niet per se een theoloog. $\mathrm{Nu}$ deze kwestie speelt in Korinthe gaat Paulus hier echter wel degelijk grondig theologisch op in. In de eerste hoofdstukken van de brief onder andere door te onderwijzen over ware wijsheid. Wat in de wereld wijs is, is bij God dwaas, en andersom. Het kruis van 
Christus zet alles op zijn kop. De Korinthiërs moeten zich niet door wereldse wijsheid laten leiden in het waarderen van leiders, maar door de Heilige Geest, die de diepten van God peilt. Paulus lijkt dit betoog af te gaan ronden, als hij in 3 vers 21 zijn praktische aansporing schrijft: 'Laat daarom niemand roemen in mensen'. Maar er komt nog een verrassend zinnetje achteraan: 'want alles is van u!' Op een retorisch sterke manier brengt hij zijn lezers van hun stuk. Zij dachten in termen van: 'ik ben aanhanger van leider $x$ of y', maar Paulus draait het hier precies om: jij bent niet van een leider, maar de leider is van jou; ja, alle leiders zijn van jou! En zelfs nog verder: ook wereld, leven, dood, tegenwoordige en toekomstige dingen zijn van jullie. (Aan het einde trouwens bewust in het meervoud: jullie in plaats van jou. Je bezit niet individualistisch, maar collectief, als gemeente.) Dit klinkt absurd! Men proeft in de gemeente van Korinthe de aantrekkingskracht die uitgaat van de verschillende leiders, en men schikt zich bewust onder de ene of de andere leider, maar Paulus doorbreekt dit schema radicaal. Men denkt namelijk in een wereldse wijsheid zo zijn vrijheid te benutten, zijn autonomie, door zelf te kiezen wat men wil, maar precies het omgekeerde gebeurt: zo onderwerpt men zich aan de macht en invloedssfeer van een leider, en is men dus helemaal niet vrij.

Paulus doorziet wat er gebeurt bij zoiets werelds als partijschappen in de gemeente. Gemeenteleden laten zich dan knechten door aardse machten. En dat is niet een sociologisch, maar een voluit theologisch probleem. Want in het evangelie gaat het juist om vrijheid. In deze Godvijandige wereld zijn er allerlei machten die hun heerschappij over de mens willen doen gelden. Dat blijkt uit het totale van de opsomming in vers 22 .

Niet alleen het leiderschap kan een knechtende factor worden; alle dingen kunnen dat. Want, zegt Paulus in hoofdstuk 6 vers 12: alle dingen zijn mij geoorloofd, maar ik zal mij niet onder de macht van wat ook maar laten brengen! De strijd van het geloof is: hebben de dingen mij, of heb ik de dingen? Al die machten en krachten in de wereld die proberen de gemeente in hun macht te krijgen: staat zij daarboven, of laat zij zich door hen intimideren? Niets minder dan de christelijke vrijheid is daarmee in het geding. Onder de oppervlakte van partijschappen in de gemeente ligt de diepte van de vrijheid van het evangelie. Paulus doet een prikkelende uitspraak om de lezer aan het denken te zetten, en dat is geen trucje, overdrijving of misleiding, maar het resultaat van een consequent doordenken van een radicale theologie. Om zijn punt te maken benut Paulus de rijke boodschap van het evangelie geheel, zowel christologisch, pneumatologisch als theocentrisch.

Ten eerste christologisch. Paulus kan zo radicaal stellen dat alles van hen is omdat hij weet dat dat in Christus waar is. In de opening van deze brief 
benoemt hij Jezus nadrukkelijk als de Heer, in wie zij 'in alles rijk geworden zijn. De Heer Jezus is de overwinnende koning die alle heerschappijen, machten en krachten aan zich aan het onderwerpen is, totdat Hij alle vijanden onder zijn voeten gelegd zal hebben (15:24b-25). Wie bij Jezus hoort deelt daarin. Daarom schrijft Paulus in vers 23 ook: 'Jullie echter zijn van Christus'. Het 'echter' zou ook met 'want' vertaald kunnen worden, want er zit iets redengevends in. Omdat we van Christus zijn, zijn alle machten aan ons onderworpen. De opsomming van machten en krachten in vers 22 komt deels overeen met de bekende opsomming in het zegelied van Romeinen 8, dat niets of niemand ons kan scheiden van de liefde van God in Christus Jezus, onze Heer. We zijn meer dan overwinnaars (8:37-39). Dit is geen reeds gerealiseerde eschatologie, maar het is wel een reeds aangebroken werkelijkheid, nu Jezus daadwerkelijk uit de dood is opgestaan en van de Vader alle macht ontvangen heeft. De gelovige heeft het steeds weer nodig om aan die werkelijkheid herinnerd te worden, om er zo ook daadwerkelijk naar te leven.

Dat brengt me bij het tweede: het pneumatologische aspect. Want Paulus' aansporing dat 'alles van jullie is', is niet bedoeld als een louter cognitieve oefening, alsof men alleen maar moet beseffen dat men bij Jezus hoort, en dat is dan de aangebroken werkelijkheid van het Koninkrijk van God. Uit de context van deze aansporing wordt juist duidelijk dat het niet alleen om iets verstandelijks gaat, maar om daadwerkelijke krachten. Aan de ene kant zijn er de krachten die ons klein proberen te krijgen, opgesomd in vers 22 . De wereld, het leven, de dood, tegenwoordige en toekomstige dingen: het zijn reële machten die heerschappij over ons proberen te krijgen. Alleen de letter van het evangelie kan die machten niet buiten de deur houden, dat kan alleen de kracht van het evangelie. Keer op keer noemt Paulus het evangelie dan ook een kracht van God. Niet alleen in het bekende vers in Romeinen 1 ('Want ik schaam mij voor het evangelie van Christus niet, want het is een kracht van God tot redding voor een ieder die gelooft'), maar ook in de context van 1 Korinthe, zoals bijvoorbeeld in hoofdstuk 4 vers 20: 'Want het Koninkrijk van God bestaat niet in woorden, maar in kracht'. Wanneer de Geest mij aan Christus verbindt, word ik van het ene krachtenveld overgezet in het andere.

In onze gereformeerde traditie zijn we steeds weer bezig met de doordenking van het evangelie van Christus, maar dat mag niet ten koste gaan van de beleving ervan. Ik word in de vrijheid van Christus geplaatst en dat is een kracht. Vanuit de gereformeerde traditie moet dan zeker op Luther teruggegrepen worden, die de vrijheid van de christen zo krachtig heeft beschreven in zijn De vrijheid van een christen. De christelijke vrijheid is kracht: 'Aangezien nu de beloften van God heilige, waarachtige, rechtvaardige, vrije en vreedzame woorden zijn, vol van alle goedheid, gebeurt het dat de ziel die door een vast 
geloof zich daaraan hecht, daarmee zó verenigd wordt, ja, zelfs zo volledig daardoor in beslag wordt genomen, dat zij niet alleen aan al hun kracht deel heeft, maar daardoor verzadigd en dronken gemaakt wordt. Want als een aanraking van Christus al genezing bracht, hoeveel temeer zal dan deze zeer tedere aanraking in de Geest, dit opgaan in het Woord, alles wat aan het Woord eigen is aan de ziel mededelen. Paulus wil de gemeente van Christus op die plek hebben: onder de heerschappij van de Geest van Christus, in eenheid met Hem. Alleen vanuit die kracht zijn partijschappen in de gemeente effectief te relativeren, en kunnen bijzaken ook echt bijzaken blijven. In het geestelijk leidinggeven aan de gemeente van Christus is het dus belangrijk om bepaalde bewegingen en dynamieken in de gemeente aan te wijzen als reële negatieve krachten die heerschappij over ons proberen te krijgen.

Ten derde is op het theocentrische aspect in deze verzen te wijzen. Dat komt naar voren in de laatste woorden van vers 23: 'en Christus is van God'. God heeft letterlijk het laatste woord. Daar komt Paulus altijd weer bij uit. Het leven in de gemeente, in het leren omgaan met de machten en krachten, heeft altijd een bepaalde gerichtheid: op God. Want 'uit Hem en door Hem en tot Hem zijn alle dingen' (Rom. 11:36). De gemeente is dan wel van Christus, die nu heerschappij voert, maar uiteindelijk zal in de voltooiing ook Christus weer zijn macht aan de Vader geven, 'opdat God alles in allen zal zijn' (15:28b). Met ruzies en partijschappen in de gemeente gaat de aandacht naar mensen, en kost dat alle energie. Dan ontbreekt de gerichtheid op God. Hierover schrijft Luther in zijn De vrijheid van een christen het volgende: '(...) En hoewel hij dus volkomen vrij is, moet hij nu toch weer gewillig een dienaar worden, om zijn naaste te helpen; hij moet zo met hem omgaan en zich zo jegens hem gedragen, als God door Christus met hém gedaan heeft. En dat alles om niet, zonder er iets anders in te zoeken dan het welgevallen van God'. Dat is compleet andere taal dan de partijleuzen van de Korinthiërs. Door de God-gerichtheid komt er ook ruimte voor de ander. Christus heeft mij de vrijheid gegeven, door de Geest als werkelijke ruimte geboden, tot het dienen van mijn naaste, omdat ik weet dat God daarvan geniet ('het welgevallen van God').

In onze tijd moeten we opnieuw oefenen hoe bevrijdend het is om niet jezelf maar God in het leven centraal te stellen. Alleen zo is er ware vrijheid. De Korinthiërs denken vrij te zijn door zichzelf of hun favoriete leider in het middelpunt te stellen, maar ze moeten leren nog veel vrijer te worden. Door op Gods heerschappij te wijzen beperkt Paulus de vrijheid van de Korinthiers niet, maar radicaliseert deze juist: 'Freier müßten die Korinther sein, frei auch von Paulus, Apollos und Kephas!', zo schrijft Wolfgang Schrage terecht bij deze tekst.

We leven in een samenleving waarin vrijheid sterk verbonden wordt aan autonomie. Ook in de kerk is dat te merken. Mensen willen vrij zijn in wie ze 
kiezen, en gaan naar de kerk of voorganger die zij vinden passen bij hun leven. Maar zo ontstaan er partijschappen. Hoe geef je daar als ambtsdrager geestelijk leiding aan? Oefen jezelf in de theologie van Paulus met zijn praktische, actuele toespitsing. Verdiep je in 1 Korinthe, en kom zo tot de kern van de christelijke vrijheid als kracht. Dat geheim moet steeds weer ontdekt worden, zoals Paulus het tweeduizend jaar geleden ontdekte en doorgaf. Zo oefen je jezelf in het ontmaskeren van de machten van deze tijd, en zet je er de kracht van het evangelie tegenover. We staan met deze taak in een rijke gereformeerde traditie. De vrijheid die Luther ontdekte is nog steeds actueel. Nog één keer De vrijheid van een christen: 'Omdat alleen het geloof genoeg is tot behoud, heb ik niets nodig dan alleen dat het geloof daarin de kracht en de macht van haar vrijheid uitoefent. Kijk, dat is de onschatbare macht en vrijheid van de christen'.

M. Bot is predikant van de christelijke gereformeerde kerk te Maassluis. 